\title{
Clinical experience with infliximab for Crohn's disease: The first 100 patients in Edmonton, Alberta
}

\author{
Clifford Sample MD, Robert J Bailey MD, Dennis Todoruk MD, Daniel Sadowski MD, \\ Leah Gramlich MD, Mario Milan MD, Raeleen Cherry MD, Mang Ma MD, \\ Eoin Lalor MB, John McKaigney MD, Richard Sherbaniuk MD, Kata Matic MD, \\ Connie Switzer MD, Richard N Fedorak MD
}

C Sample, RJ Bailey, D Todoruk, et al. Clinical experience with infliximab for Crohn's disease: The first 100 patients in Edmonton, Alberta. Can J Gastroenterol 2002;16(3):165-170.

OBJECTIVE: To determine whether the clinical efficacy and safety of infliximab in diverse clinical referral practices was similar to that seen in the randomized, controlled clinical trials. METHODS: Data were gathered from a review of charts of 109 consecutive patients with inflammatory and/or fistulizing Crohn's disease who received infliximab infusions. Responses were recorded based on the physician's global clinical assessment and classified as complete, partial or nonresponse.

RESULTS: One hundred nine patients were treated with one to nine infusions of infliximab at a dose of $5 \mathrm{mg} / \mathrm{kg}$ and followed up for a median of 24 weeks (range one to 40 weeks). Fifty-four patients were treated for inflammatory disease, 38 for fistulizing disease and 17 for both. Clinical response occurred in 73\% (17\% complete response, 55\% partial response). The clinical response rate did not vary relative to patient demographics, disease distribution, indication for infliximab, or the concomitant use of corticosteroids or immune modifiers. For those taking concomitant immune modifiers, the response rate was $75 \%$. The median time to response was two weeks (range one to six weeks). The median duration of response was 12 weeks (range six to 88 weeks). Reduction or cessation of steroids was possible in 17 of 32 patients. Adverse events related to infliximab occurred in $7 \%$ of patients. These events were characterized as mild and did not require stoppage of infliximab therapy, except in one patient who had a treatable anaphylactic-like infusion reaction.

CONCLUSIONS: The patient group in the present study realized significant clinical benefit, with minimal adverse effects, following treatment with infliximab. Clinical response rates paralleled those previously described in placebo controlled trials and retrospective clinical practice reviews. Nevertheless, the complete response rate (ie, remission) in this patient group was lower than that previously described.

Key Words: Clinical remission; Clinical response; Crohn's disease; Inflammatory bowel disease; Immunosupression; Infliximab

Résumé à la page suivante

Division of Gastroenterology, University of Alberta, Edmonton, Alberta

Correspondence and reprints: Dr Richard N Fedorak, Division of Gastroenterology, University of Alberta, 519 Robert Newton Research Building,

Edmonton, Alberta T6G 2C1. Telephone 780-407-6941, fax 780-407-3744, e-mail Richard.fedorak@ualberta.ca

Received for publication October 4, 2001. Accepted January 14, 2002 


\section{Expérience clinique de l'infliximab chez les 100 premiers patients atteints de la maladie de Crohn, à Edmonton, en Alberta}

OBJECTIF : Vérifier si l'efficacité clinique et l'innocuité de l'infliximab dans différents contextes de renvoi sont semblables aux résultats observés dans les essais cliniques comparatifs avec répartition aléatoire.

MÉTHODE : Nous avons revu les dossiers de 109 patients consécutifs atteints d'une maladie de Crohn inflammatoire ou fistuleuse, qui ont reçu des perfusions d'infliximab. Les réactions ont été notées d'après l'évaluation clinique globale des médecins et classées comme complètes, partielles ou réfractaires.

RÉSULTATS : Cent neuf patients ont reçu de une à neuf perfusions d'infliximab à raison de $5 \mathrm{mg} / \mathrm{kg}$ et ont été suivis pendant une période médiane de 24 semaines (étendue de 1 à 40 semaines). Cinquante-quatre patients ont été traités pour une maladie inflammatoire, 38 pour une maladie fistuleuse et 17 pour les deux types de maladie. Il y a eu réaction clinique dans $73 \%$ des cas (réaction complète : $17 \%$; réaction partielle : $55 \%)$. Le taux de réaction clinique n'a pas varié en fonction des données démographiques des patients, de la distribution de la maladie, des indications de l'infliximab ou de l'utilisation concomitante de corticostéroïdes ou de modificateurs immunitaires. Le taux de réaction a atteint $75 \%$ chez les patients prenant en même temps des modificateurs immunitaires. Le temps médian de réaction a été de deux semaines (étendue de 1 à 6 semaines) et la durée médiane de réaction, de 12 semaines (étendue de 1 à 40 semaines). Il a été possible de réduire, voire de cesser, l'utilisation des stéroïdes chez 17 patients sur 32. L'infliximab a produit des effets indésirables chez $7 \%$ des patients. Ces effets ont été jugés bénins et n'ont pas justifié l'interruption du traitement à l'infliximab, sauf chez un patient qui a présenté une réaction de type anaphylactique à la perfusion, réaction qui a d'ailleurs cédé au traitement.

CONCLUSION : Les patients à l'étude ont tiré des bienfaits cliniques significatifs du traitement à l'infliximab, tout en n'éprouvant que peu d'effets indésirables. Les taux de réaction clinique se comparent à ceux enregistrés antérieurement dans des essais cliniques contre placebo et des examens rétrospectifs de pratique clinique. Toutefois, le taux de réaction complète (entendre « rémission ») dans le groupe s'est avéré inférieur aux données déjà recueillies.
$\mathrm{I}_{\mathrm{w}}^{\mathrm{n}}$ nflammatory bowel disease (IBD) is the result of an unchecked intestinal inflammatory response. While the exact etiology and pathogenesis of IBD are unclear, the inflammatory response is likely initiated by luminal factors, likely bacteria or bacterial products that serve as activating antigens. By sieving through a permeable epithelial barrier, these initiating factors in turn lead to an increased exposure of the mucosal immune system to luminal antigens and toxins. In the genetically susceptible individual, this process results in an inappropriate and perpetuating mucosal immune response, with ensuing macroscopic tissue injury.

Immunosuppressors used in the treatment of IBD include azathioprine, 6-mercaptopurine, methotrexate, mycophenolate mofetil, cyclosporine, tacrolimus and newer compounds such as infliximab that are biologically engineered. There is growing evidence that these compounds are useful for the treatment of chronically active, steroid-dependent or steroid-resistant Crohn's disease, permitting disease remission and corticosteroid withdrawal.

Infliximab is a murine chimeric monoclonal antitumour necrosis factor-alpha antibody. Recent clinical trials have shown its efficacy in treating moderate to severely active and fistulizing Crohn's disease (1-4). Reviews of the clinical experience at three major American IBD referral centres have revealed an efficacy and steroid-sparing effects that are similar to those seen in controlled clinical trials (5-7).

We examined the initial clinical experience with infliximab in the treatment of refractory inflammatory and fistulizing Crohn's disease at four referral hospitals in the city of Edmonton, Alberta, with respect to its clinical efficacy and safety. The objective of the present study was to determine whether the clinical efficacy and safety of infliximab in diverse clinical practices were similar to those seen in the clinical trials.

\section{MATERIALS AND METHODS}

Infliximab was available either through compassionate release or through clinical trials. All gastroenterologists in Edmonton were contacted to determine whether they had treated patients with infliximab. Records of patients who had received infliximab via compassionate release programs $(n=101)$ were reviewed, as were the records of patients who had received an initial dose of infliximab as part of the Accent I and Accent II clinical trials initiated by Centocor Inc (USA) and then entered the compassionate release program $(n=8)$. For patients who participated in these two clinical trials, no clinical trial data were used for the purposes of the present paper. Instead, the treating physician's global clinical response assessment following a known infusion of infliximab $5 \mathrm{mg} / \mathrm{kg}$ was recorded.

The charts of patients who had received at least one infusion of infliximab for the induction treatment of luminal inflammatory Crohn's disease and three infusions for the induction treatment of fistulizing Crohn's disease, and who had received at least one clinical follow-up visit were reviewed. Data were extracted for the following parameters: patient demographics, indication for infliximab infusion, duration of Crohn's disease, immediate previous medical therapies for the management of Crohn's disease and concurrent therapies (including dose of prednisone at beginning and end of therapy), disease distribution, previous surgery, surgery during infliximab therapy, type of infliximab induction (single- or triple-infusion induction), total number of infusions, requirements for premedication to prevent adverse infusion reactions, time to onset of clinical response, duration of clinical response and adverse events.

Infliximab was administered as a $5 \mathrm{mg} / \mathrm{kg}$ intravenous infusion; no patients received $10 \mathrm{mg} / \mathrm{kg}$ infusions. The type of induction used was at the treating physician's discretion, 
as was the administration of subsequent doses and their timing. Patients with inflammatory disease received a single induction dose, while those with fistulizing disease received three induction doses at zero, two and six weeks.

Response was determined at the time of clinical followup, based on the treating physician's global assessment of the patient, and did not reflect a defined scoring system. Clinical follow-up initially occurred between four and eight weeks after an infusion of infliximab. All patients were subsequently followed up at least every eight months throughout the duration of the review. To evaluate an unselected group of patients, a simple evaluation reported in an earlier study was paralleled (5). Clinical response was divided into three categories: complete response (remission), partial response and nonresponse. Complete response was defined as a cessation of fistula drainage and total closure of all fistulae, and/or cessation of abdominal cramping and diarrhea. A partial response was defined as a reduction in number, size, drainage or discomfort associated with the fistulae and/or a decrease in abdominal cramping and diarrhea. All other outcomes were considered nonresponses.

Statistical analysis was performed using SPSS 9.0 for Windows (SPSS Inc, USA). The $t$ test was used for quantitative variables and the $\chi^{2}$ test for qualitative variables. $\mathrm{P}<0.05$ was considered statistically significant.

\section{Patient characteristics}

\section{RESULTS}

A total of 109 patients, 57 men and 52 women treated by 13 gastroenterologists, were included in the study. The median age was 42.5 years (range 18 to 79 years). Patient demographic characteristics, including previous and current medical and surgical therapy, and concomitant medical treatment are summarized in Table 1. Indications for infliximab therapy were inflammatory Crohn's disease (54 patients [50\%]), Crohn's fistulae (38 patients [35\%]), and both inflammatory and fistulizing Crohn's disease (17 patients [16\%]). The median follow-up was 24 weeks (range six to 88 weeks).

\section{Treatment with infliximab}

Patients received between one and nine infusions of infliximab $5 \mathrm{mg} / \mathrm{kg}$. Patients with fistulizing disease received three doses of infliximab over six weeks as induction therapy. Forty-three of the 80 patients who initially responded were retreated with additional doses of infliximab for maintenance of remission. The majority of infliximab infusions $(98 \%)$ were administered in an outpatient setting.

\section{TABLE 1}

\begin{tabular}{|c|c|}
\hline \multicolumn{2}{|c|}{$\begin{array}{l}\text { Demographics and characteristics of patients with } \\
\text { inflammatory and/or fistulizing Crohn's disease who } \\
\text { were treated with infusions of infliximab }\end{array}$} \\
\hline \multicolumn{2}{|l|}{ Demographics } \\
\hline Mean age, years (range) & $39.2(18-79)$ \\
\hline $\begin{array}{l}\text { Mean duration of disease, } \\
\text { years (range) }\end{array}$ & $12.4(1-31)$ \\
\hline Extraintestinal manifestations ( $\mathrm{n}$ ) & $11 / 109$ \\
\hline Previous total parenteral nutrition therapy ( $n$ ) & $8 / 109$ \\
\hline Previous surgery for Crohn's disease (n) & $75 / 109$ \\
\hline \multicolumn{2}{|l|}{ Disease distribution } \\
\hline Small bowel only $(\mathrm{n})$ & $25 / 109$ \\
\hline Colon only (n) & $14 / 109$ \\
\hline Small bowel and colon $(\mathrm{n})$ & $70 / 109$ \\
\hline \multicolumn{2}{|l|}{ Indication for infliximab } \\
\hline Inflammatory only (n) & $54 / 109$ \\
\hline Fistulae only (n) & $38 / 109$ \\
\hline Inflammatory and fistulae (n) & $17 / 109$ \\
\hline \multicolumn{2}{|l|}{ Previous medications } \\
\hline Mesalamine (n) & $93 / 109$ \\
\hline Methotrexate (n) & $28 / 109$ \\
\hline 6-Mercaptopurine (n) & $6 / 109$ \\
\hline Azathioprine (n) & $76 / 109$ \\
\hline Cyclosporine (n) & $16 / 109$ \\
\hline Corticosteroids (n) & $103 / 109$ \\
\hline
\end{tabular}

Infliximab-induced clinical response

The clinical outcomes of the 109 patients are shown in Table 2. The median time to response was two weeks (range one to six weeks), and the median duration of response was 12 weeks (range six to 88 weeks).

Overall, a clinical response (complete or partial as defined above in the 'Methods') was achieved in 80 of 109 $(73 \%)$ patients following the initial infusion (Table 2 and Figure 1). Twenty-nine (27\%) patients had no response. Within the group of responders (including those with inflammatory, fistulizing, and both inflammatory and fistulizing diseases), 61 of 109 (55\%) had a partial response, while 19 of 109 (17\%) had a complete response. Of 54 patients treated for inflammatory Crohn's disease, 36 (67\%) responded (52\% partial response and 15\% complete response). Of 38 patients treated for fistulizing Crohn's disease, $31(82 \%)$ responded (53\% partial response and 29\% complete response). Of 17 patients treated for both inflammatory and fistulizing Crohn's disease, 13 (76\%) responded (76\% partial response and 0\% complete response).

\section{TABLE 2}

Clinical response to infliximab therapy in patients with inflammatory and/or fistulizing Crohn's disease

\begin{tabular}{lcccc}
\hline & $\begin{array}{c}\text { All disease } \\
\text { groups }(\mathbf{n = 1 0 9 )}\end{array}$ & $\begin{array}{c}\text { Inflammatory } \\
\text { disease only }(\mathbf{n = 5 4 )}\end{array}$ & $\begin{array}{c}\text { Fistulizing } \\
\text { disease only }(\mathbf{n = 3 8 )}\end{array}$ & $\begin{array}{c}\text { Inflammatory and } \\
\text { fistulizing disease }(\mathbf{n = 1 7})\end{array}$ \\
\hline Response, $\mathrm{n}(\%)$ & $80(73)$ & $36(67)$ & $31(82)$ & $13(76)$ \\
Complete response, $\mathrm{n}(\%)$ & $19(17)$ & $8(15)$ & $11(29)$ & $0(0)$ \\
Partial response, $\mathrm{n}(\%)$ & $61(55)$ & $28(52)$ & $20(53)$ & $13(76)$ \\
No response, $\mathrm{n}(\%)$ & $29(27)$ & $18(33)$ & $7(18)$ & $4(24)$ \\
\hline
\end{tabular}




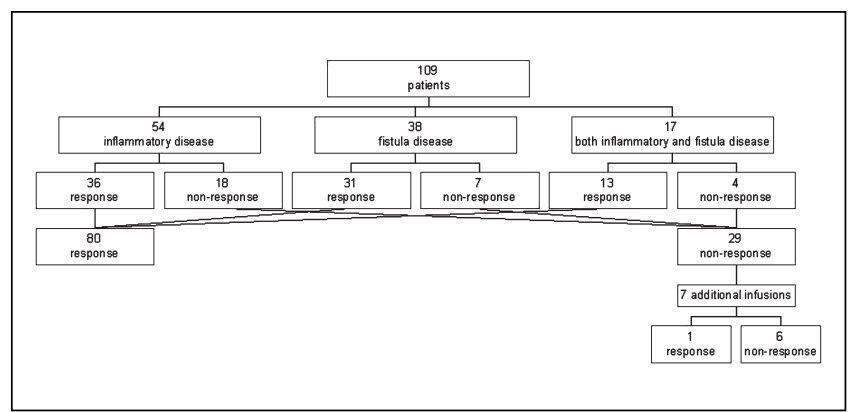

Figure 1) Outcomes of 109 patients with inflammatory and/or fistulizing Crohn's disease treated with infliximab. non-resp Nonresponse

The patient demographics and characteristics did not differ significantly between responders and nonresponders (Table 3). Furthermore, response rates did not differ between those with and those without concomitant immune modifiers ( $75 \%$ and $71 \%$, respectively; $\mathrm{P}=0.568$ ), or with the number of infliximab infusions used for induction (one-, two- or three-dose infliximab: $73 \%, 100 \%$ and $73 \%$, respectively; $\mathrm{P}=0.696$ ). The mean duration of response in patients using concomitant immune modifiers at the time of the infliximab infusions was 14 weeks, while the duration of response in patients not using immune modifiers was 13.5 weeks $(\mathrm{P}=0.912)$.

Of the disease sites, colonic disease seemed to respond most favourably to treatment with infliximab. The response rate was $60 \%$ in those with Crohn's disease isolated to the small bowel, $100 \%$ in those with Crohn's disease isolated to the colon and $73 \%$ in those with Crohn's disease that involved both the small bowel and the colon; however, this difference did not reach statistical significance $(\mathrm{P}=0.051)$. In addition, the response rate did not vary relative to disease type; the response rate was $67 \%$ for patients with inflammatory disease, $82 \%$ for those with fistulizing disease, and $76 \%$ for those with both inflammatory and fistulizing disease $(\mathrm{P}=0.267)$.

\section{Corticosteroid tapering}

During the initiation and interval of infliximab therapy, 32 patients were receiving concomitant corticosteroid therapy. Seventeen patients $(53 \%)$ were able to reduce the dosage of corticosteroid used; of those, nine $(28 \%)$ were able to discontinue corticosteroid use.

\section{Maintenance treatment with infliximab}

Of the initial 80 patients who demonstrated a response to infliximab, 43 received one to eight additional infusions of infliximab to maintain response, with a median interval of eight weeks (range four to 56 weeks). Forty of the 43 patients continued to respond clinically to a second infusion of infliximab. Of the 29 patients who did not respond to the initial infusion, seven were given an additional infusion of infliximab. Of those, only one had a clinical response. An algorithm of the clinical outcomes with maintenance infusions is shown in Figure 2.

\section{Adverse events}

A total of 16 adverse events were recorded to be related to infliximab. Eight of 109 (7\%) patients had immediate adverse events that were characterized as being related to

\section{TABLE 3}

\section{Characteristics and demographics of patients with inflammatory and/or fistulizing Crohn's disease who responded} (responders) or did not respond (nonresponders) to treatment with infliximab

\begin{tabular}{|c|c|c|c|}
\hline & Responders $(n=80)$ & Nonresponders $(n=29)$ & $\mathbf{P}$ \\
\hline \multicolumn{4}{|l|}{ Demographics } \\
\hline Mean age, years (range) & $38.0(18-78)$ & $40.8(25-79)$ & 0.128 \\
\hline Mean duration of disease, years (range) & $11.8(1-31)$ & $14.1(2-26)$ & 0.478 \\
\hline Male:female & $42: 38$ & $15: 14$ & 0.943 \\
\hline Smoker, n (\%) & $9(11)$ & $2(7)$ & 0.494 \\
\hline Extraintestinal manifestations, $\mathrm{n}(\%)$ & $6(8)$ & $5(17)$ & 0.281 \\
\hline Previous total parenteral nutrition, $\mathrm{n}(\%)$ & $7(9)$ & $1(3)$ & 0.348 \\
\hline Previous surgery, $\mathrm{n}(\%)$ & $55(69)$ & $20(69)$ & 0.983 \\
\hline \multicolumn{4}{|l|}{ Disease distribution } \\
\hline Small bowel only, $\mathrm{n}(\%)$ & $15(19)$ & $10(34)$ & \\
\hline Colon only, n (\%) & $14(18)$ & $0(0)$ & \\
\hline Colon and small bowel, $\mathrm{n}(\%)$ & $51(64)$ & $19(66)$ & 0.051 \\
\hline \multicolumn{4}{|l|}{ Indication for infliximab } \\
\hline Inflammatory disease only, $\mathrm{n}(\%)$ & $36(45)$ & $18(62)$ & \\
\hline Fistulizing disease only, $\mathrm{n}(\%)$ & $31(39)$ & $7(24)$ & \\
\hline Inflammatory and fistulizing disease, $\mathrm{n}(\%)$ & $13(16)$ & $4(14)$ & 0.267 \\
\hline \multicolumn{4}{|l|}{ Concomitant medication } \\
\hline 6-Mercaptopurine, azathioprine, methotrexate, n (\%) & $56(70)$ & $19(66)$ & 0.571 \\
\hline Mesalamine, $\mathrm{n}(\%)$ & $18(23)$ & $8(28)$ & 0.210 \\
\hline Corticosteroid, $\mathrm{n}(\%)$ & $22(28)$ & $10(34)$ & 0.528 \\
\hline
\end{tabular}


the infliximab infusion, including headache, light-headedness, shortness of breath and rash. Only one patient had to discontinue the infliximab treatment because of an 'anaphylactic'-type reaction. In the other seven patients, the infusions were continued at a slower rate after administration of diphenylhydrate and/or acetaminophen. Other adverse reactions that were characterized as possibly related to the infliximab infusion included a flare of gout (one patient), diffuse transient joint pain (one patient), chest pain (one patient two days after the infusion), rash (four patients, one of which discontinued therapy) and activation of varicella zoster (one patient).

Ten of 29 patients (34\%) required surgery for their Crohn's disease. One patient required resection of a stricture but did not have active disease at the time of resection. A second patient had closure of an ileostomy after resolution of fistulae. A third patient had a reversal of a Hartman's procedure after improvement of symptoms. The remainder of the patients - seven of $29(24 \%)$ - underwent surgery for nonresponse to infliximab therapy.

\section{DISCUSSION}

Our initial clinical experience with infliximab for the treatment of Crohn's disease correlates well with the initial placebo controlled studies (1-4), as well as with three retrospective studies from the United States describing response and adverse events in clinical practice settings (5-7).

The demographics of our group of patients were similar to those of patients in previously published retrospective clinical studies (5-7). All patients had severe Crohn's disease with inadequate response to conventional therapy. The median duration of disease was 11.8 years. With respect to the use of immune modifiers, 75 of 109 patients given infliximab were receiving concomitant azathioprine, 6-mercaptopurine or methotrexate. A significant number of patients treated with infliximab were, therefore, not following the recently published Canadian guidelines for the use of infliximab in Crohn's disease (8). These guidelines state that, provided that no contraindication exists, patients with Crohn's disease who require therapy with infliximab should be considered for concomitant treatment with immunosuppressive therapy. The reason for this discrepancy is not clear; however, it may be that infliximab was administered before the dissemination of the guidelines or that infliximab was started as part of a clinical trial in which concomitant immunomodulatory therapy was not permitted. Nevertheless, it is interesting to note that the rate of global clinical response in patients who received immune modifiers $(70 \%)$ was not different from that seen in all patients $(73 \%)$. The finding that concomitant administration of immune modifiers in patients with Crohn's disease did not alter the response rates to infliximab infusions is similar to previously demonstrated results (5-7) but contrasts with those seen when infliximab has been used in the treatment of rheumatoid arthritis (9).

One hundred three of 109 patients with Crohn's disease in our study had failed to achieve remission with corticos-

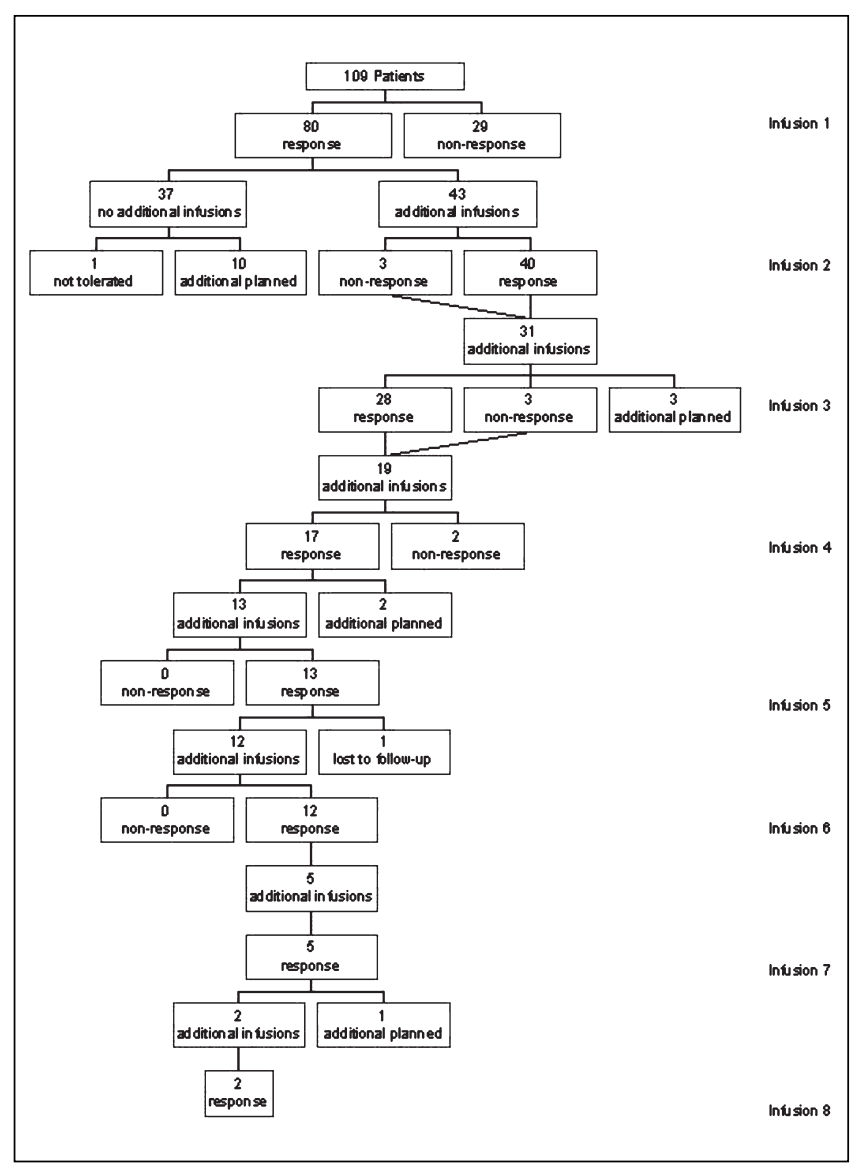

Figure 2) An algorithm of clinical outcome of Crohn's disease with maintenance infusions of infliximab. non-resp Nonresponse

teroids. Initiating infliximab treatment in this corticosteroid-refractory group of patients achieved an overall clinical response rate in all disease groups of $73 \%(17 \%$ complete response and 55\% partial response) (Table 2).

The results of our Edmonton retrospective clinical practice review were similar to those reported from three IBD referral centres in the United States (Rochester, Minnesota; Chicago, Illinois; and Providence, Rhode Island). The results for clinical response in inflammatory luminal and fistulizing Crohn's disease in the Edmonton study $(67 \%$ and $82 \%$, respectively) were similar to those previously published from Rochester, Minnesota (72\% and 64\%, respectively) (5), Chicago, Illinois (65\% and 78\%, respectively) (6) and Providence, Rhode Island (60\% and 69\%, respectively) (7).

In contrast to the similar clinical responses to infliximab seen among these centres, the percentage of patients with inflammatory luminal and fistulizing Crohn's disease determined to have a complete response (ie, remission) in the Edmonton study (15\% and 29\%, respectively) was noticeably less than the percentages identified from Rochester, Minnesota (52\% and 34\%, respectively) (5), Chicago, Illinois (31\% and 24\%, respectively) (6) and Providence, Rhode Island (60\% and 64\%, respectively) (7). The exact reason for this discrepancy is unclear because all studies 
used similar methodological clinical end points to determine remission. However, it is very likely that the differences are related to patient and physician interpretation and assessment of 'complete remission'.

When the results of the retrospective Edmonton clinical practice review were compared with those reported in the randomized, placebo controlled, clinical trial with infliximab, the response rates were found to be similar (73\% and $81 \%$, respectively) (2). Nevertheless, the complete response rate was lower in the present study than in the earlier studies (17\% and 48\%, respectively) (2). The reasons for these differences likely relate to both patient inclusion criteria and definition of response.

The median time to response was two weeks, and the median duration of response was 12 weeks - similar to the results from previous studies (4-7).

In our treatment group, 17 of 32 (53\%) patients taking concomitant corticosteroids were able to reduce or eliminate their requirements for corticosteroids. In addition, the mean dose of corticosteroids (prednisone) before $(5.6 \mathrm{mg}$ ) and after infliximab (3.6 mg) decreased significantly $(\mathrm{P}=0.019)$. This magnitude of corticosteroid sparing is similar to that described previously in retrospective clinical reviews from Rochester, Minnesota (73\%) (5), Chicago, Illinois (69\%) (6) and Providence, Rhode Island (40\%) (7).

For patients who did not respond to the initial dose of infliximab, subsequent doses of infliximab resulted in only a $14 \%$ response rate, suggesting that patients who do not respond to an initial dose of infliximab are unlikely to respond to subsequent doses. This finding is similar to that identified in the Providence, Rhode Island study (12\%) (7), but is slightly lower than that described in the Rochester, Minnesota study (30\%) (5) or the clinical trial by Targan et al (34\%) (2).

Immediate adverse events attributed to infliximab infusion by the treating gastroenterologist were infrequent (7\%), and generally minor and self-limited; only one patient required discontinuation of therapy due to an anaphylactic-type infusion reaction. Similar infusion-related adverse events were seen in the data available from the retrospective clinical practice reviews from Rochester Minnesota (19\%) (5), Chicago, Illinois (6\%) (6), and
Providence, Rhode Island (25\%) (7). The long term safety of infliximab relative to the development of neoplasia (10) and reactivation of latent tuberculosis (11) remains under investigation.

\section{CONCLUSIONS}

Our patient group realized significant clinical response rates, with minimal adverse effects, following treatment with infliximab. This clinical response rate paralleled those described in placebo controlled trials (1-4) and retrospective clinical practice reviews (5-7). Nevertheless, the complete response (remission) rates in our patient group were lower than those described previously $(2,5-7)$.

\section{REFERENCES}

1. Van Dullemen HM, van Deventer SJH, Hommes DW, et al. Treatment of Crohn's disease with anti-tumor necrosis factor chimeric monoclonal antibody (cA2). Gastroenterology 1995;109:129-35.

2. Targan SR, Hanauer SB, van Deventer SJH, et al. A short-term study of chimeric monoclonal antibody cA2 to tumor necrosis factor alpha for Crohn's disease. N Engl J Med 1997;337:1029-35.

3. Rutgeers P, D'Haens G, Targan S, et al. Efficacy and safety of retreatment with anti-tumor necrosis factor antibody (infliximab) to maintain remission in Crohn's disease. Gastroenterology $1999 ; 117: 761-9$.

4. Ricart E, Panaccione R, Loftus EV, Tremaine WJ, Sandborn WJ. Successful management of Crohn's disease of the ileoanal pouch with infliximab. Gastroenterology 1999;117:429-31.

5. Ricart E, Panaccione R, Loftus EV, Tremaine WJ, Sandborn WJ. Infliximab for Crohn's disease in clinical practice at the Mayo Clinic: the first 100 patients. Am J Gastroenterol 2001;96:722-9.

6. Cohen RD, Tsang BS, Hanauer SB. Infliximab in Crohn's disease: first anniversary clinical experience. Am J Gastroenterol 2000;95:3469-77.

7. Farrell RJ, Shah SA, Lodhavia PJ, et al. Clinical experience with infliximab: Therapy in 100 patients with Crohn's disease. Am J Gastroenterol 2000;95:3490-7.

8. Panaccione R, Fedorak RN, Feagan B, et al. Canadian Association of Gastroenterology Clinical Practice Guidelines: The use of infliximab in Crohn's disease. Can J Gastroenterol 2001;15:367-70.

9. Maini R, St Clair EW, Breedveld F, et al. Infliximab versus placebo in rheumatoid arthritis patients receiving concomitant methotrexate: a randomised phase III trial. Lancet 1999;354:1932-9.

10. Bickston SJ, Lichtenstein GR, Arseneau KO, Cohen RB, Cominelli F. The relationship between infliximab treatment and lymphoma in Crohn's disease. Gastroenterology 1999;117:1433-7.

11. Keystone EC. Tumor necrosis factor-alpha blockade in the treatment of rheumatoid arthritis. Rheum Dis Clin North Am 2001;27:427-44. 
In the article, "Clinical experience with infliximab for Crohn's disease: The first 100 patients in Edmonton, Alberta", which appeared in the May 2002 issue of The Canadian Journal of Gastroenterology (pages 165-170), the name of one of the authors, Mario Millan, was spelled incorrectly. 


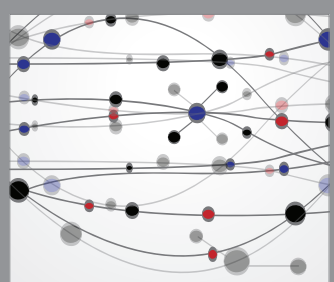

The Scientific World Journal
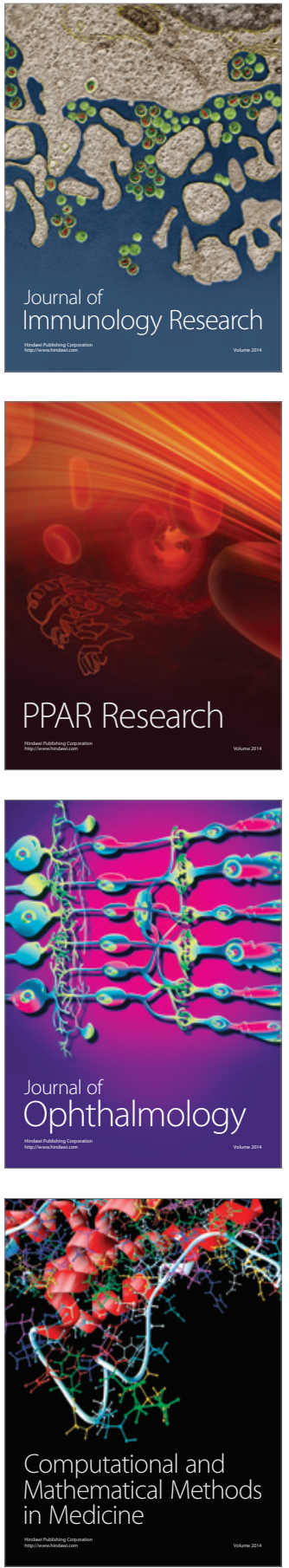

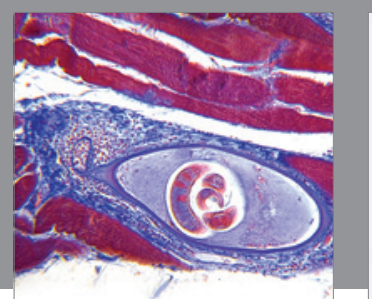

Gastroenterology Research and Practice

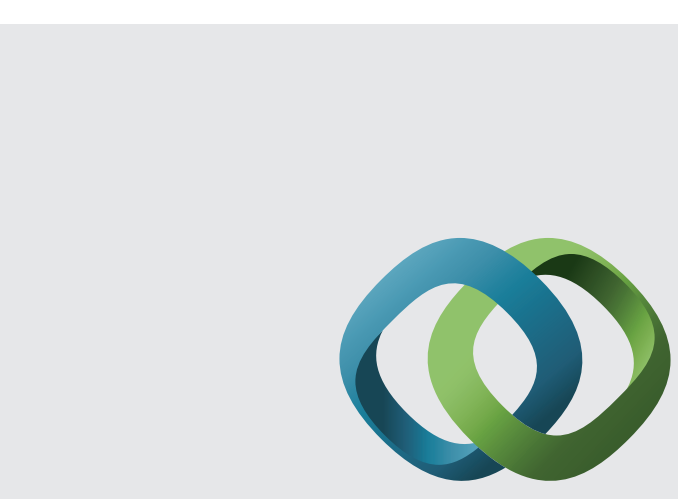

\section{Hindawi}

Submit your manuscripts at

http://www.hindawi.com
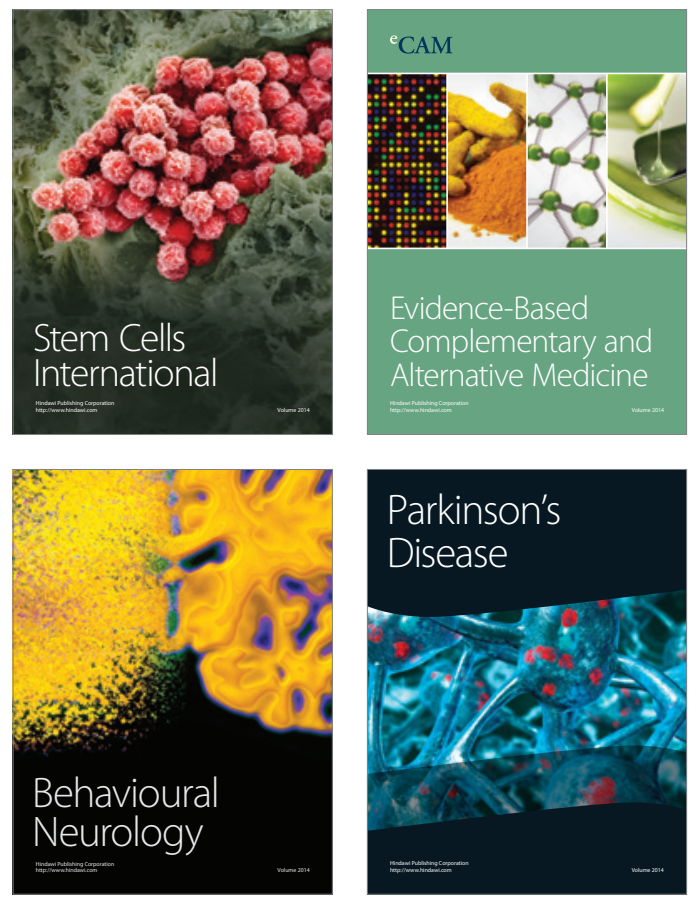
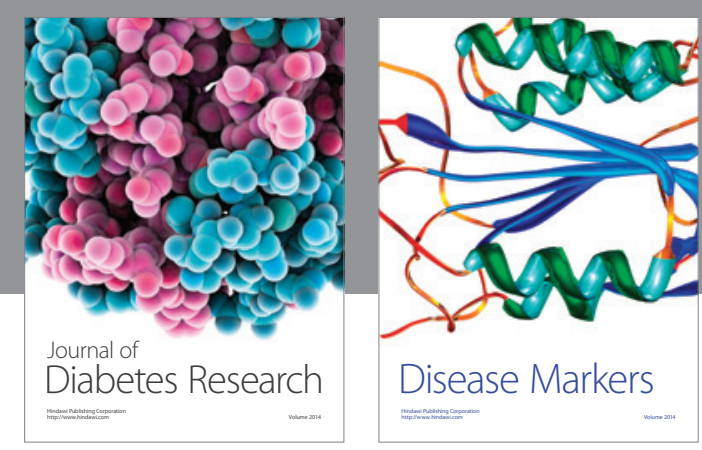

Disease Markers
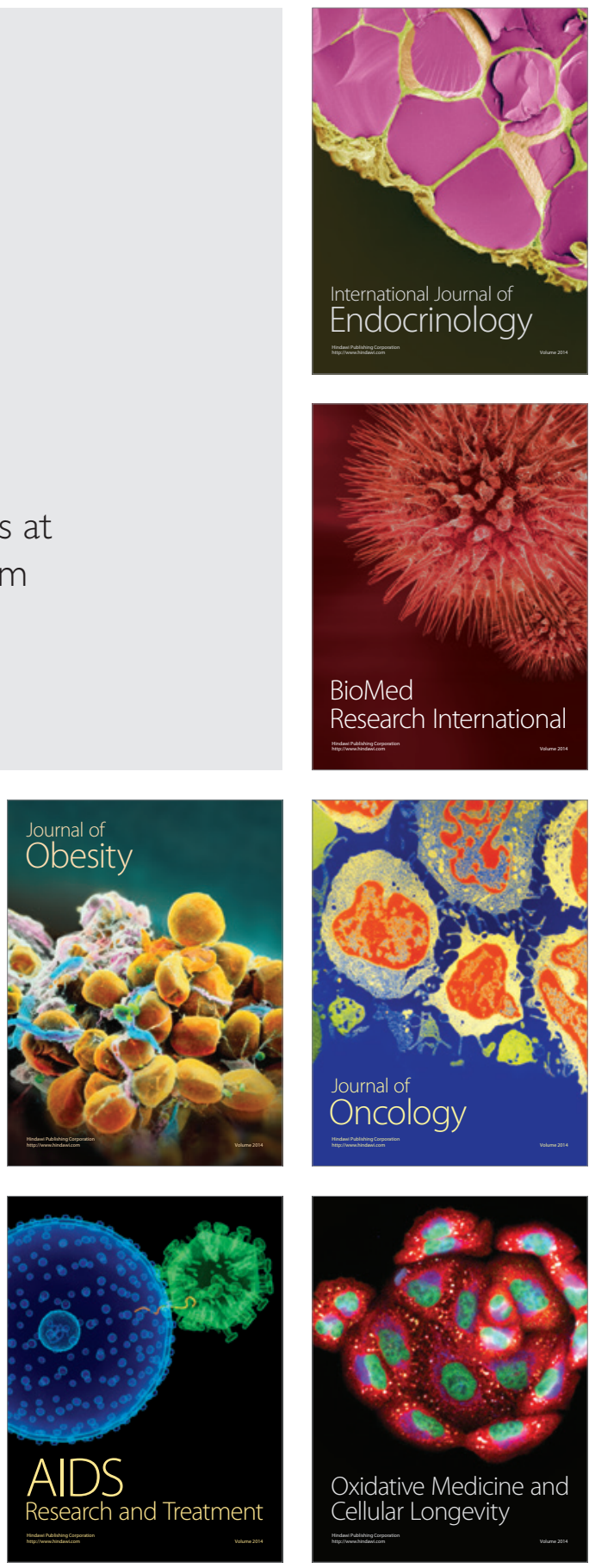